\title{
ANALYSIS AND EVALUATION OF VICTORIAN REFORM IN GENERAL DAMAGES FOR PERSONAL INJURY UNDER THE TORT OF NEGLIGENCE
}

\author{
JOHN CHU*
}

[This article examines the current legislative structures in Victoria for compensating non-economic losses for personal injuries under the tort of negligence. It first provides a background on the tort of negligence in general and damages for non-economic losses in particular. It then outlines the changes that have swept through Victoria and in the rest of Australia for comparative purposes. This article offers a critique of the rationale and justification for those changes, analyses the implications of the changes at both Victorian and Commonwealth levels across the public, professional and product liability areas, and concludes with a discussion of the overall effect of the Victorian reforms.]

\section{INTRODUCTION}

Of all the matters into which the Review of the Law of Negligence ('Ipp Panel') was requested to inquire... the principles governing the award of damages arising from personal injury and death was... most critical. It is reform of that area of law which is liable to have the most significant affect on our day to day lives and on the community at large. ${ }^{1}$

\footnotetext{
* B Info Sys, B Bus (Bkg \& Fin), MBA (Monash), CPA, CMC, JD Candidate, Faculty of Law, University of Melbourne.

${ }^{1}$ Nicholas J Mullany, 'Tort Reform and the Damages Dilemma' (2002) 25(3) UNSW Law Journal 876, 876.
} 
It is obvious that not everything can be contracted in advance when it comes to human interactions. As such the tort of negligence provides an important legal framework to help safeguard an individual's personal safety in the course of everyday life, in the absence of deliberate acts committed by a person to inflict injuries on another.

One of the, if not the, most challenging and contentious area in the law of negligence is the assessment and award of general damages. It is therefore no surprise that they are the major focus of the supposed tort reform in Australia. Naturally Victoria has participated in this national movement along with the other states and territories, though the changes implemented by governments are by no means uniform.

Given the increasingly vocal backlash in New South Wales and to a certain extent in some other states and territories against what growing sections of society see as deformation of their rights and entitlements under this significant cause of action, it is timely to evaluate current legislative arrangements of relevance to Victoria for compensating non-economic loss pursuant to personal injuries due to negligence.

\section{TORT OF NEGLIGENCE}

Negligence law is a fault regime to effect unmediated corrective justice between a wrongdoer and a victim through the restitutionary measure of damages employed to correct the fault. ${ }^{2}$ As such tort law conventionally has been understood to be exclusively about corrective justice. ${ }^{3}$ But actually it has a number of objectives to fulfil: ${ }^{4}$

- compensation function - fair and just recompense for injured persons;

- promotion of safety or "deterrent" function - the encouragement of the highest standards in safety and risk management; and

\footnotetext{
${ }^{2}$ Bruce Feldthusen, 'Posturing, Tinkering and Reforming the Law of Negligence A Canadian Perspective?' (2002) 25(3) UNSW Law Journal 854, 856.

${ }^{3}$ Stephen D Sugarman, 'Tort Reform Through Damages Law Reform: An American Perspective' (2005) 27(3) Sydney Law Review 507, 507.

${ }^{4}$ Law Council of Australia, Insurance and Personal Injury Law - Why Do We Have Them? (2003) < http://www.lawcouncil.asn.au/get/publications/2384814030.PDF> at 25 November 2006
} 
- corrective justice or responsibility function - a just allocation among wrongdoers of responsibility for compensation.

It is argued that the law of negligence: ${ }^{5}$

- provides deterrence by requiring people to pay damages to those they harm since people will be less inclined to engage in dangerous or careless behaviour if they, rather than society at large, are required to bear the cost of that negligence;

- enforces individual responsibility by requiring people to take responsibility for their actions, either by paying for the damage they cause or by obtaining appropriate insurance to meet those losses.

The operation of the law of negligence is said to have the following advantages in terms of: ${ }^{6}$

- conforming to society's expectation that persons who cause injury to others by their fault must pay for the harm caused;

- avoiding a need for self-help, including violent self-help as the courts order damages to be paid upon a finding of fault;

- enhancing safety awareness by imposing a damages judgment on an individual or enterprise at fault for tortfeasors will normally take greater care in the future to avoid liability and publicity in the media also serves as a general deterrent for other potential defendants.

\section{General Damages}

The traditional purpose of tort damages at common law is to provide complete compensation for the victim's loss by forcing a wrongdoer who has caused harm to pay for everything necessary to make the specific plaintiff whole as awards are highly individualised as to their amount, so as to reflect the unique circumstances of every case. ${ }^{7}$ A judge or a jury hears the evidence of loss and awards an amount of damages based on the economic and noneconomic losses suffered by that claimant so as to return the plaintiff to the

\footnotetext{
${ }^{5}$ Tim Bugg, 'Negligence and damages - personal injury, property damage and pure economic loss' (Speech delivered at the Fiji Law Society 50th Anniversary Convention, Fiji, 26 May 2006).

${ }^{6}$ Judd Epstein, 'Is the Law of Negligence Still Appropriate for Australia?' (2006) 18(2) Legaldate 1, 1.

${ }^{7}$ Sugarman, above n 3, 507.
} 
position before the incident insofar as money can do so. ${ }^{8}$ The person whose negligence has caused an injury is required to compensate the victim, on a once and for all basis, for all past present and future loss. ${ }^{9}$

It is only fair that those harmed by another's negligence should, as far as is reasonably possible, be restored to the position they were in prior to the injury or damage for the basic principle is that those who suffer harm through the fault of another should be compensated for their losses, in which "harm" covers all forms of injury or loss, including: ${ }^{10}$

- temporary or permanent physical impairment or restriction;

- damage to personal property, and

- pure economic loss, encompassing past losses and predicted future loss of income and opportunity.

Non-economic loss arising from personal injury is loss 'based neither on lost income nor on out-of-pocket financial payments made (or owed) by victims' and examples of which include 'physical pain and suffering that goes along with a physical trauma, the emotional harm that can come from an injury to one's self or a loved one, the disappointment or embarrassment coming from one's changed appearance or altered abilities to engage in pleasurable activities and favourite pastimes as a result of an injury, the harm to one's dignity from being wrongly injured by another, and so on. ${ }^{, 11}$

Therefore non-economic loss which is also referred to as non-pecuniary loss, is loss which is not itself monetary in character and includes the following major categories: ${ }^{12}$

- pain and suffering,

- loss of amenities;

- loss of life expectancy; and

- disfigurement.

\footnotetext{
${ }^{8}$ Epstein, above n 6.

${ }^{9}$ Reg Graycar, 'Public Liability: A Plea for Facts' (2002) 8(2) University of New South Wales Law Journal - Forum 2, 2.

${ }^{10}$ Bugg, above $\mathrm{n} 5$.

${ }^{11}$ Sugarman, above n 3, 512 .

${ }^{12}$ Law Council of Australia, Tort Law Reform Resource Kit: Module A - Thresholds and Damages for Non-Economic Loss (2004) [Backgrounder - Damages for Noneconomic Loss and Thresholds] <http://www.lawcouncil.asn.au/shared/ $2404306316>$ at 26 November 2006.
} 
Loss of amenities refers to the inability of a victim to enjoy life as he or she has before the injury in terms of, for example, the ability to work, play sport, engage in hobbies, marry, have children, realise ambition or achieve sexual satisfaction; whereas loss of expectation of life is loss of prospective happiness resulting from reduction of an injured person's life expectancy. ${ }^{13}$

Sometimes non-economic loss is simply referred to as pain and suffering, as that is often the most significant component of non-economic loss in a particular case, ${ }^{14}$ and damages, as in compensation, for non-economic loss are also referred to as "general damages" or "damages for pain and suffering". "Underlying the award of general damages is the idea that money can provide the plaintiff with some consolation for having been injured. ${ }^{16}$ It is suggested that functions of an award of damages for non-pecuniary loss include: ${ }^{17}$

- as a palliative;

- to enable the purchase of alternative sources of satisfaction, and

- to meet hidden expenses.

\section{CiRcumstances Behind TORT Reform}

It is useful to recap the background of the lead-up to the reform, especially for those unfamiliar with the subject. Clark and McInnes have provided an overview which has been summarised as follows: ${ }^{18}$

The Commonwealth, and each State and Territory have introduced reforms in an attempt to deal with the 'crisis' perceived to be gripping the law of negligence and Australia's legal system.

\footnotetext{
${ }^{13}$ Helen Coonan, 'Reform of Liability Insurance Law in Australia' (The Treasury of the Commonwealth of Australia, 2004), 82.

${ }^{14}$ Law Council of Australia, above $\mathrm{n} 12$.

${ }^{15}$ Law Council of Australia, Thresholds for General Damages (2004)

$<$ http://www.lawcouncil.asn.au/get/publications/2404048740.pdf $>$ at 25 November 2006 .

${ }^{16}$ Coonan, above $\mathrm{n} 13,82$.

${ }^{17}$ Law Council of Australia, above n 15.

${ }^{18}$ S Stuart Clark and Ross McInnes, 'Unprecedented Reform: The New Tort Law' (2004) 15(2) Insurance Law Journal 1, 1-3.
} 
These reforms have their origins in the so called public liability crisis which emerged in late 2001/early 2002.

It was suggested that parts of Australia's legal system were 'out of control' while sections of the community began to criticise the 'culture of blame' which was said to have become entrenched in Australian society.

These opinions were fuelled by a combination of factors including the collapse of both a major insurer and a medical indemnity organisation, spiralling premiums and a number of highly publicised awards of damages. There were also concerns that insurance for many socially useful activities including medicine, volunteer activities and community organisations and events, was either no longer available or so expensive as to be unaffordable.

Drivers of the 'crisis' [are:]

Community attitude

A fundamental force underlying the liability crisis is the litigious mindset entrenched in many individuals within the community.

The development of the tort of negligence

From the 1960s to the 1990s judicial expansion of the concept of negligence was ubiquitous. During this time the courts manifestly extended the circumstances in which negligence may be found to have occurred and the scope of damages recoverable.

The downturn in the insurance industry cycle

Insurance industry experts and analysts have partially attributed the present liability crisis to the cyclical nature of the insurance industry.

The emergence of specialist plaintiff law firms: Legal advertising and 'no win no fee' arrangements 
The growth of specialist plaintiff law firms, particularly in the area of personal injury, has been pinpointed as contributing to the increased propensity of people to make a claim following injury.

Plaintiffs' law firms have also taken advantage of the deregulation of legal fees, including the introduction of contingency uplift fees and 'no win no fee' arrangements, to draw business. There is a view that the manifestation of 'no win no fee' and like arrangements merely encourages claims (often said to be unmeritorious) and ultimately results in an increase in insurance costs.

\section{Class actions}

Since the enactment of legislation governing class action procedure at a federal and State level, there have been several high profile class actions in Australia, particularly in the area of product liability. While to date few actions have proceeded to hearing, it is argued that the emergence of representative proceedings as a means of recourse has materially influenced overall insurance costs and the community's attitude towards access to justice.

It is often overlooked that besides the public liability insurance crisis, there was also a medical indemnity insurance crisis. Specifically:

Particular problems were caused in 2002 when UMP the largest medical indemnity insurer in Australia went into provisional liquidation as a result of a number of pressures, including poor management in the 1990s, underprovisioning for long-tail claims, a sharp increase in premiums and the failure of its re-insurer, HIH. Additional problems were caused by the withdrawal of insurer St Paul from the primary medical indemnity insurance market and the implementation of financial restrictions imposed by the Australian Prudential Regulation Authority (APRA) and its new prudential 
standards, including those relating to minimum capital requirements. $^{19}$

In addition, 'there was an influential body of legal opinion that had become critical of the operation of the common law, arguing that the standard of care imposed on defendants had become too stringent, the levels of care required of potential plaintiffs for their own safety had been unacceptably reduced, that principles of causation had been stretched to barely tolerable limits and that the principles on which damages are awarded were in at least some respects too generous. ${ }^{20}$ As a result, a judicial 'reform' as distinguished from the subsequent legislative 'reform', of the common law of negligence has been well underway by the time the insurance crisis has erupted, as Cappa, Forrest, Hinchy and Nase have pointed out: ${ }^{21}$

$[\mathrm{P}]$ rior to the 'insurance crisis' and the National Review of the Law of Negligence...the High Court had sought to return to basics and to redevelop a principled approach to the law of negligence. The High Court has endeavoured to do so not only in determining the duty of care element, but more importantly, to toughen the standard of care requirements that determine breach of that duty.

[J]udicial decisions also reflect the significant shift in society towards accepting personal responsibility, which has not always been reflected in the inadequate weight given to the conduct of the plaintiff over past decades.

\section{State of Play across Australia}

Whilst changes implemented by all Australian jurisdictions since 2002 can be broadly categorised into three types which are establishing liability, damages and claims procedures, those made to the laws of damages are aimed at removing the smaller claims from the system while setting appropriate limits on particular heads of damage for very large ones. ${ }^{22}$

\footnotetext{
${ }^{19}$ Law Council of Australia, above n 12, Backgrounder - Medical Negligence.

${ }^{20}$ John Keeler, 'Personal Responsibility and the Reforms Recommended by the Ipp Report: 'Time Future Contained in Time Past' (2006) 14(1) Torts Law Journal 48, 49. ${ }^{21}$ Clare Cappa, Craig Forrest, Russell Hinchy and Vernon Nase, 'Tort Deform or Tort Reform? Winding Back the Clock on Negligence' (2003) 28(5) Alternative Law Journal 212, 213.

${ }^{22}$ Coonan, above n $13,7-8$.
} 
Governments achieve the aim by introducing caps and thresholds on general damages. A cap is a maximum amount of damages that can be awarded by courts. A threshold is a barrier to access to damages such that compensation is only received if a victim satisfies a minimum level in terms of monetary value, permanent impairment, or the worst conceivable case. ${ }^{23}$

The current legislative framework on the award of general damages for each jurisdiction in Australia is summarised in Table 1.

Whilst the Trade Practices (Personal Injuries and Death) Act 2004 (Cth) restricts claims for general damages arising from death or personal injury where those proceedings relate to Part IVA (unconscionable conduct), Division 1A (product safety and product information) or 2A (actions against manufacturers and importers of goods) of Part V or Part VA (liability of manufacturers and importers of defective goods), it does not apply to Division 1 of Part V (unfair practices), of the Trade Practices Act 1974 (Cth) ${ }^{24}$ But following the enactment of the Trade Practices Amendment (Personal Injuries and Death) Act 2006 (Cth), damages for non-smoking related personal injury or death are no longer recoverable for a contravention of the provisions relating to unfair practices, such as ss $52,53 .^{25}$

Given the focus of this paper, greater details on the Victorian legal regime concerning general damages for personal injury are provided herewith. The impairment assessment process includes the following steps: ${ }^{26} 27$

- Unless the respondent gives a waiver, a claimant has to be assessed by a medical practitioner who has undertaken an approved course in accordance with the Accident Compensation Act 1985 (Vic).

\footnotetext{
${ }^{23}$ Law Council of Australia, above n 15.

${ }^{24}$ John Morgan and Matthew Skinner, Civil Liability Reform - Recent

Commonwealth Legislation - Finishing Touches? (2004) Allens Arthur Robinson

$<$ http://www.aar.com.au/pubs/insur/pap04aug04.htm> at 25 November 2006, 8 .

${ }^{25}$ The Trade Practices Act 1974 (Cth) s 82 (1AAA).

${ }^{26}$ Joanne Girgenti and Ben Hall, Victoria's Second Tranche of Civil Liability

Reforms (2003) FindLaw Australia <http://www.findlaw.com.au/article/8996.htm $>$ at 24 November 2006.

${ }^{27}$ Louise Radloff, Andrew Saxton and George Triantopoulos, Tort Reform in Action Across the East Coast (2005) Ebsworth \& Ebsworth Lawyers

$<$ http://www.ebsworth.com.au/ebsworth/website/eepublishing.nsf/Content/Publicatio n_Paper_TortReform_17Mar05>.
} 
- A medical practitioner must provide a certificate of assessment that states whether the level of impairment meets the relevant threshold.

- A claimant can seek the respondent's agreement to waive the requirement of a certificate and the respondent has 60 days in which to respond to such request.

- A respondent either accepts the assessment in writing or disputes it within 60 days by referring it to a Medical Panel constituted under the aforementioned Accident Compensation Act at its own cost. Otherwise a failure to respond results in a 'deemed acceptance' of the assessment on the part of the respondent.

- A Medical Panel must give its binding opinion in writing within 60 days after the referral is made.

- A defendant can waive the assessment process but must do so in writing acknowledging it is the proper defendant and accepting the injury is a significant injury.

- Upon receiving a request for waiver, if a defendant considers it is not the proper defendant it must give reasons for this belief and any information that may assist the plaintiff to identify that party.

- Where there are multiple defendants, one defendant can act on behalf of the others for the purpose of the assessment process subject to the consent of the other defendants.

To pass the threshold for general damages, the injury must be permanent and as such it probably does not include mere trespass to the person or false imprisonment. ${ }^{28}$ All impairments arising out of an incident must be included in the one assessment. ${ }^{29}$ A Medical Panel's reassessment is final and must be accepted by the court unless the panel has not followed proper procedures. ${ }^{30}$

'[T]he WorkCover and Transport Accident Schemes have been untouched by the reforming Acts, ${ }^{31}$

\footnotetext{
${ }^{28}$ James Ruddle, The Wrongs \& Other Acts (Law of Negligence) Act 2003 - What are the Changes (26 February 2004) Victorian Government Solicitor's Office $<$ www.vgso.vic.gov.au/documents/wrongs.pdf > at 26 November 2006, 6.

${ }^{29}$ Michael Martin, Victorian Tort Law Reform Continues (2003) Sparke Helmore $<$ http://www.sparke.com.au/file?publication/3617> at 26 November 2006.

${ }^{30}$ Coonan, above n $13,84$.

${ }^{31}$ Michael Lombard and Michael McGarvie, "Its OK to Say Sorry But Can You Sue?" - Victoria's Personal Injury Reforms (2003) Holding Redlich [3]

$<$ www.holdingredlich.com.au/articles/637662_1.PDF> at 25 November 2006.
} 


\section{CRItICISMS Against THE REFORM}

' $[C]$ hanges that parliaments have enacted don't deserve the title 'reform' [since] changes for the better...is what 'reform' meant... ${ }^{32}$

Given the sweeping nature of the legislative changes made, it is only natural that since the so-called reform began, the validity of the underlying justifications has been questioned by scholars, practitioners and members of the public. Indeed a high level literature survey quickly shows widespread concerns on all the major facets of the entire reform. An understanding of these concerns provides the context for analysing the implications in Victoria.

The spectrum of criticisms against the changes can be grouped into the areas of premise, objective, rationale, process and outcome. With many seeing the Ipp Panel as having given the impetus to tort reform, it is not surprising that its review report has attracted much scrutiny and condemnation.

The premise for change is a fundamental starting point of any critique on the reform. In this respect, not only was the "Ipp Panel not permitted to challenge the premise that negligence law was "unpredictable"; nor that it was "too easy" for plaintiffs to recover; nor that damages were "too high"... it reached the conclusion that the perception alone was sufficient to justify reform' since it did "gather "evidence" that negligence law was so perceived by some members of the Australian public. ${ }^{33}$ Moreover '[w]hether or not the operation of the principles of negligence law and the assessment of damages was responsible for the fund failures and increases in insurance premiums that helped to provoke the crisis was not included in the terms of reference and the Ipp Panel did not investigate and formed no view about the relationship between them or the likely impact of its recommendations on the insurance market. ${ }^{34}$ Indeed, according to Feldthusen, ' $[\mathrm{t}]$ he mandate given to the Ipp Panel posits that "damages for personal injury has become unaffordable and unsustainable as the principle source of compensation for those injured by the fault of another" and identifies "[t]he solution to the problem...[namely,] limiting liability and quantum of damages"”, but:

\footnotetext{
32 John North, 'Beyond the Pain Threshold' (Speech delivered at the Personal Injury and Compensation Forum of Law Council of Australia, Sydney, 3 June 2005) [1-2] $<$ www.lawcouncil.asn.au/shared/2413401029> at 25 November 2006.

${ }^{33}$ Feldthusen, above n 2, 857.

${ }^{34}$ Keeler, above n 20, 50 .
} 
Both the problem and the type of solution appear to have been stated by fiat, with no underlying empirical evidence in support. Nor was the Ipp Panel empowered to investigate or challenge either. Strikingly absent is any desire to investigate alleged malfunction in the private insurance market. ${ }^{35}$

If the premise of reform is not beyond reproach then its objective naturally is not either. As Mullany has said, '[b]ased on highly questionable, certainly unproven, premises, Ipp Panel was required, inter alia, to: "develop and evaluate principled options to limit ... quantum of awards for damages". ${ }^{36}$ On the other hand "tort law reforms explicitly designed to reduce both the number and value of personal injury claims could be expected to alleviate an insurance crisis (albeit not by addressing its causes). ${ }^{37}$

Furthermore Davis contends that the Review of the Law of Negligence has not 'critically examine[d] the case that has been argued by the insurance industry for tort reform [which he] finds it empty of substance' and is 'flawed for three reasons':

First, the Review arose out of the insurers' public campaign for tort reform, a campaign big on rhetoric but scant on facts. Second, the terms of reference of the Ipp Review were designed so as to deny any analysis of the truth of insurer's claims about the causes of premium increases. Third, the membership of the Review committee was stacked with persons ideologically committed to tort reform regardless of the true causes for premium increases. ${ }^{38}$

Other disparagement of the reform process centres on its hastiness:

Tort reform has not been approached in a comprehensive and principled way. Governments wanted the quickest fix for skyrocketing premiums without looking at the other side of the equation: what compensation do victims of negligence need, and how best can that need be met? ${ }^{39}$

\footnotetext{
${ }^{35}$ Feldthusen, above n 2, 856 .

${ }^{36}$ Mullany, above n 1, 876.

${ }^{37}$ E W Wright, 'National Trends in Personal Injury Litigation: Before and After "Ipp"' (Law Council of Australia, 2006), 29-30.

${ }^{38}$ Rob Davis, 'The Tort Reform Crisis' (2002) 25(3) University of New South Wales Law Journal 865, 865.

${ }^{39}$ Robert Pelletier, Tort Reform Needs an Injection of Fairness (2005) FindLaw Australia <http://www.findlaw.com.au/article/13654.htm> at 24 November 2006 .
} 
[T]here is evident a seemingly unflinching political determination to rush to reform irrespective of the merits of the cases for and against that momentous step. ${ }^{40}$

Another aspect of the reform that has attracted much denigration is the lack of conclusive evidentiary support to justify the changes. Graycar has highlighted that:

In its September 2002 report, the Australian Health Ministers Advisory Council Legal Process Reform Group ('Neave Committee') on medical indemnity issues was careful to acknowledge that there really is insufficient data to blame litigation for the insurance crisis. ${ }^{41}$

Graycar elaborates further by quoting from the Neave Committee report:

Many changes which are suggested as so-called tort reforms are simply benefit reductions, which if not well-considered will have the effect of increasing the harm and disadvantage suffered by those people who are most in need of assistance. Cost containment is an appropriate aim for reform. However the ... basis for changes [must be] justified by the evidence. ${ }^{42}$

Bugg adds to this view by saying that:

[T] ort law reforms were hastily-introduced and ill-thought out. They were a knee-jerk reaction to a problem that, according to this hard data, had little or nothing to do with litigation rates... ${ }^{43}$

Bugg's perspective is supported by Wright who states in his report that: ${ }^{44}$

[T] he direct premise on which the Ipp Review proceeded was not that claim numbers were increasing but rather something a little different, namely that personal injury claims were becoming increasingly successful and were resulting in increasingly larger awards. However, neither the Ipp Review nor the coterie of government

\footnotetext{
${ }^{40}$ Mullany, above $\mathrm{n} 1,876$.

${ }^{41}$ Graycar, above n 9, 4 .

${ }^{42}$ Ibid.

${ }^{43}$ Lawyers Weekly, Final Report: No Justification for Tort Reforms (2006)

$<$ http://www.lawyersweekly.com.au/articles/1E/0C04101E.

asp Type $=53 \&$ Category $=853>$ at 25 November 2006 .

${ }^{44}$ Wright, above n 37, 29-30.
} 
policy makers responsible for implementing its recommendations had empirical confirmation of these supposed facts either. The data required to confirm the "widely held view" that these were the facts was (and is) simply not available. If, however, it was indeed the case that it had become "in recent times too easy" for plaintiffs to succeed in personal injury cases, and to obtain damages awards that were "frequently too high", one would surely expect an evident rise in claims over time. We did not find this trend.

It is evident that the reformers could have had no empirical foundation, either for predicting the impact of the reforms on personal injury litigation in their jurisdictions, or for determining by how much it was desirable to reduce it.

These are not facts which inspire confidence in the reform process.

Given the abovementioned censure of the reform, it is to be expected that its outcome draws the most stinging denunciation. In general, Pelletier opines that:

$[\mathrm{T}]$ ort reform as it has proceeded in Australia in recent years ... has been, according to the Chief Justice [Spigelman], a response to a perceived crisis in the price and availability of insurance. We have applied a plaster to stem the rise in premiums in the short term without looking at questions of fairness and proper compensation. ${ }^{45}$

Feldthusen also comments on the superficiality of the reform solution in that ' $[t]$ he problem they identified was the perception that, it is too easy to recover in negligence', accordingly ' $[\mathrm{t}] \mathrm{h}$ he solution they recommended was to create the perception that this would be so no longer ... [i]f we leave aside the provocative questions of how such a perception arose, how it was proven, and how it might be corrected, as did the Panel'. ${ }^{46}$

At a jurisdictional level, it has been said that:

\footnotetext{
${ }^{45}$ Pelletier, above $\mathrm{n} 39$.

${ }^{46}$ Feldthusen, above n 2, 856.
} 
The unfairness and inconsistency of the NSW system of personal injury laws shows little evidence of being the product of a logical policy determination. ${ }^{47}$

It appears that both the Personal Injuries Proceedings Act 2002 and the Civil Liability Act 2003 are a solution to what is simply thought may be a problem. The solution is proposed before the nature of the problem is identified. ${ }^{48}$

Overall it is said that:

Currently the system is out of balance [with the] three very important functions of negligence law have been severely diluted:

- fair and just compensation for people injured through fault has become, in many instances, a thing of the past;

- individuals and organisations no longer have the same tort law deterrence from employing poor safety and risk management practices; and

- personal responsibility among wrongdoers has been diminished. $^{49}$

The insurance crisis is nothing compared to the crisis our society faces from underwriter driven tort reform. The current round of tort reform has caused enormous and permanent damage to the integrity of Australia's legal system. ${ }^{50}$

\section{A Critique of CoOnan's 'MANifesto’}

Any evaluation of the reform will not be complete without examining the perspective of its chief proponent, Senator Helen Coonan who as the then Minister for Revenue and Assistant Treasurer has 'bulldozed' her way through all the criticisms to pave the way for its implementation. Her essay, 'Insurance Premiums and Law Reform - Affordable Cover and the Role of

\footnotetext{
${ }^{47}$ The Law Society of New South Wales, 'Personal and Public Responsibilities in Injury Compensation' (2006) (April) Law Society Journal 57, 57.

${ }^{48}$ Cappa, Forrest, Hinchy, and Nase, above n 21, 215.

${ }^{49}$ North, above n 32, 2, 5 .

${ }^{50}$ Davis, above n 38,870 .
} 
Government', 51 presents her views or at least those which she represents, subscribes or endorses, for justifying the reform. Although it is published in the University of New South Wales Law Journal, it hardly qualifies as an academic exegesis for it is full of hyperbole but short on proofs. It is therefore aptly described as a manifesto.

The major claims in her article together with commentators' counterpoint are as follow.

Claim 1:

There is a widely held view that the current problems in the insurance market are due in large part to the operation of the legal system. It is clear that the broader community is dissatisfied with the seemingly random nature of court awards. ${ }^{52}$

Counterpoint:

[C]hanges were justified on the grounds that they reflected 'community concerns' or 'changing community standards or values'. One may be sceptical as to where and how those community standards could ever be reliably discovered by anyone, let alone courts; whether in fact there is much consensus in the community on many of these issues at all; and, even if there were, whether those community standards are, at worst, capricious and, at best, changeable and reflective of particular circumstances as they arise.(McDonald) $)^{53}$

The Queensland Parliament, however, has had some difficulty in distinguishing between principle and policy, and, under the guise of reform, has sought to legislate on principles currently being worked through by the High Court.(Cappa, Forrest, Hinchy, and Nase) ${ }^{54}$

\footnotetext{
${ }^{51}$ Helen Coonan, 'Insurance Premiums and Law Reform - Affordable Cover and the Role of Government' (2002) 8(2) UNSW Law Journal 7.

${ }^{52}$ Coonan, above n 51, 7.

${ }^{53}$ Barbara McDonald, 'The Impact of the Civil Liability Legislation on Fundamental Policies and Principles of the Common Law of Negligence' (2006) 14(3) Torts Law Journal 268, 299.

${ }^{54}$ Cappa, Forrest, Hinchy, and Nase, above n 21, 215.
} 
A Macquarie University study reported in The Financial Review on 4 June suggests that damages awards before 2000 were not excessive.(Gordon) ${ }^{55}$

\section{Claim 2:}

There is also a strong perception that an increasing culture of blame has emerged within our society. This has led individuals to seek redress through the legal system, where in similar circumstances in the past, the individual would have been more prepared to assume responsibility for the consequences of their own actions. ${ }^{56}$

Counterpoint:

[I]nsurance premiums have indeed risen substantially, but there is no actual evidence that this is linked to tort claims or to our becoming an increasingly litigious or 'blame' society. ... [O]ne of the biggest problems facing our community is that we link blame to compensation, rather than accept collective responsibility for those who, because of injury or illness or disability, are unable to care for themselves.(Graycar) ${ }^{57}$

Claim 3:

It is the Commonwealth Government's view that the area in which it can make the largest contribution to resolving the current state of the insurance market is by providing leadership to State and Territory Governments to encourage reform of the law to stabilise the level of litigation. $^{58}$

Counterpoint:

Overall, therefore, the court statistics appear to support a view that there has been a steady increase in public liability insurance bodily

\footnotetext{
${ }^{55}$ John Gordon, The State of the Insurance Market: "Crisis? What Crisis?" (2004) Australian Insurance Law Association <www.aila.com.au/research/2004_papers/ GordonJ.pdf $>$ at 1 December 2006, 3.

${ }^{56}$ Coonan, above n 51, 7.

${ }^{57}$ Graycar, above n 9, 4-5.

${ }^{58}$ Coonan, above n 51, 7.
} 
injury claims over the last five to ten years. There is no evidence of an 'explosion of litigation' in recent years.(Atkins and Pearson) ${ }^{59}$

The Productivity Commission Report 2001 reported civil litigation rates falling $4 \%$ for 4 years. The ACCC said there was no link between litigation rates and premiums (Dr David Cousins 13/6/02). The Commonwealth's own actuaries said "There is no evidence of an explosion in litigation in recent years" (Report to Heads of Treasury 30 May 2002). ... Insurance industry data demonstrated claims per policies issued had fallen in the 10 years since 1992 ... Surveys of County and District Court registries around the country showed no significant increase in rates of public liability claims or damages awarded... [A] survey of 700 community organisations by ourcommunity.com in March 2002 found 96\% had made no public liability claim in 5 years. Of claims made, payouts over the 5 years represented $3.5 \%$ of premiums collected in one year. The average claim was $\$ 8875$ and only two claims exceeded $\$ 50,000$. Researchers at Curtin University studied the claims history of over 800 sporting groups across Australia and New Zealand and found that only 3\% had made public liability claims in the last 10 years.(Gordon) ${ }^{60}$

Claim numbers grew from 43,000 in $1992 / 93$ to 78,000 in $1999 / 00$, an increase of $81 \%$, but:

- policy numbers grew from 1.23 million in1992/93 to 3.01 million in 1999/200, an increase of 145\%; (Cumpston Sarjeant [sic]) ${ }^{61}$

Average public liability settlement by private insurers increased from $\$ 7,600$ in $1992 / 93$ to $\$ 13,200$ in $1999 / 00$, but:

- insurance excesses have increased in same period meaning threshold to make a claim has increased, and with it, average claim costs. (Cumpston Sarjeant [sic]) ${ }^{62}$

\footnotetext{
${ }^{59}$ Geoff Atkins and Estelle Pearson, 'Public Liability Insurance: Practical Proposals for Reform' (Trowbridge Consulting, 2002), 59.

${ }^{60}$ Gordon, above n 55, 3-4.

${ }^{61}$ Ron Heinrich, 'Public Liability: Slipping and Falling or Regaining Balance?'

(Paper presented at the AFR Insurance Summit 2002, Sydney, 29 November 2002)

[Slide 14] <http://www.lawcouncil.asn.au/read/2002/2362703091.html > at 26

November 2006.

${ }^{62}$ Ibid, Slide 15.
} 
Claim 4:

$[\mathrm{N}]$ eed to act quickly ${ }^{63}$

Counterpoint:

[A]fter its Report was released on 2 October 2002, there was barely any time for or attempt at consultation on its recommendations. The second, much more substantial, stage of the Civil Liability reforms was enacted in Parliament barely three weeks later. It would seem that the criticism of legislation as "hastily and inconsiderately adopted'... might be well deserved here.(McDonald) ${ }^{64}$

\section{Claim 5:}

The Panel sought to strike a balance between the interests of injured people and those of the community at large and to impose a reasonable burden of responsibility on individuals to take care of others and to take care of themselves. ${ }^{65}$

Counterpoint:

Any reform aimed at increasing the responsibility of people for their own safety in the face of dangers created by others necessarily runs the risk of causing significant injustices by tipping the balance too far.(Keeler) ${ }^{66}$

The effect of these provisions is that an injured claimant subsidises the costs of cutting insurance premiums. Those who act negligently are partially relieved of the consequences of their default, as is their insurer, to the detriment of the victim of their negligence, and possible the broader community."(de Jersey) ${ }^{67}$ "In the course of the debate, much was said about reasserting a need for people to accept

\footnotetext{
${ }^{63}$ Coonan, above $\mathrm{n} 51,8$.

${ }^{64}$ Barbara McDonald, 'Legislative Intervention in the Law of Negligence: The Common Law, Statutory Interpretation and Tort Reform in Australia' (2005) 27 (3)

Sydney Law Review 443, 445.

${ }^{65}$ Coonan, above n 51,8 .

${ }^{66}$ Keeler, above n 34, 79.

${ }^{67}$ LAWASIAdownunder2005, 'Personal Responsibility Must Cut Both Ways, Says

Queensland Chief Justice' (Press Release, 22 March 2005) [2]

$<$ http://www.lawcouncil.asn.au/shared/2411396054> at 26 November 2006.
} 
responsibility for their own actions. That must however work both ways. A difficultly about these provisions, arguably, is that they suggest the wrongdoer is to a degree being protected.(de Jersey) ${ }^{68}$

Claim 6:

Insurance is a vital thread running through the fabric of our society...[and] [a] better outcome is getting the settings right to ensure the market works more effectively. ${ }^{69}$

Counterpoint:

Insurance crises that result in sudden large increases in premiums are a recurring phenomenon. States became monopoly motor vehicle third party insurers because private insurers withdrew from that market and there were insurance crises (especially in the fields of third party and workers compensation insurance) in 1958-1960, the mid-1970s and the mid-1980s.(Keeler) ${ }^{70}$

These factors...:

- loss of capacity by international re-insurers and insurers following a series of natural disasters and the tragedy of September 11, 2001;

- the collapse of the HIH Insurance Group (which the Law Council notes had about a fifth of the public liability market);

- the substantial fall in the value of worldwide equities markets over the last eighteen months (estimated to be over \$US100bn); and

- the financial strictures imposed by the Australian Prudential Regulation Authority (APRA) of new Prudential standards, in particular the minimum capital requirements.

...contribute to, and make it possible to realise a desire of the remaining insurers, who are effectively monopoly or near-monopoly providers to a captive market, to make profits or recoup prior years' losses due to underpricing in prior periods.(Heinrich) ${ }^{71}$

Australian liability insurers (like their counterparts in Canada and the US) have traditionally (and willingly) operated with negative underwriting results, relying instead on investment returns for their

\footnotetext{
${ }^{68}$ Ditto.

${ }^{69}$ Coonan, above n 51, 9.

${ }^{70}$ Keeler, above n 34, 48.

${ }^{71}$ Heinrich, above n 61, 5 .
} 
profits. Indeed, APRA statistics reveal that over the last 20 years Australian general insurers, in aggregate, have never booked a positive underwriting result.(Davis) ${ }^{72}$

Average price rises of $30 \%$ in $2001 / 2002$, but:

- premiums were unrealistically low in previous years;

- as a percentage of GDP, premiums are back to 1986-1987 levels.(Heinrich) $)^{73}$

Particular (one-off?) pressure affect this year, namely HIH exit, September 11 and APRA requirements. Insurance companies will be in profit next year without any changes.(Heinrich) ${ }^{74}$

\section{Claim 7:}

Once implemented, a nationally consistent negligence law will provide a more efficient system for the allocation and management of risk. $^{75}$

Counterpoint:

The aspiration of national consistency was expressed by Commonwealth, State and Territory Ministers on 15 November 2002 at a Ministerial meeting on public liability insurance. The Ministers agreed in principle on a package of reforms designed to implement the key recommendations of the Ipp Report.... In so doing, the Ministers noted that the legislation introduced in NSW provided a model to develop nationally consistent reform.(Clark, Harris and Mclnnes) ${ }^{76}$

Although the Commonwealth Government may have had uniform legislation in mind when it asked a panel to review the law of negligence and to make recommendations for legislation to rein in negligence claims, it is unfortunate that legislation from State to State, though similar in many provisions, is not uniform overall. Not

\footnotetext{
${ }^{72}$ Davis, above n 38, 869.

${ }^{73}$ Heinrich, above n 61, Slide 12.

${ }^{74}$ Ibid, Slide 13.

${ }^{75}$ Coonan, above n 51, 10.

${ }^{76}$ Stuart Clark, Christina Harris and Ross Mclnnes, 'Tort Reform Take Two' (2003) (February) Law Society Journal 54, 54.
} 
only is there variation in the provisions, there is often also a difference in the stated objectives of the tort reform legislation, which can only cause greater diversity in interpretation of some of the more generalised or ambiguous provisions.(McDonald) $)^{77}$

The challenge for insurers is even more profound. Underwriters seeking to price a particular risk will need to assess the likelihood of the relevant risk occurring across eight separate legislative frameworks. This will not be a particularly easy task for any underwriter of public liability risks.(Kearney) ${ }^{78}$

Claim 8:

[T]here are good prospects that premiums should be stabilised and that there will be downward pressure on premiums in the mid to longer-term. ${ }^{79}$

Counterpoint:

The changes to legislation in the States in the aftermath of the Ipp Report produced a reduction in the number and cost of claims, but at best a stabilisation of insurance premiums. Any more recent reduction in them is likely to result more from the restoration of investment income and the effects of competition in pursuit of market share than from the effects of that legislation.(Keeler) ${ }^{80}$

Claim 9:

Law reform is central to dealing with the problem. ${ }^{81}$

\footnotetext{
${ }^{77}$ Barbara McDonald, 'The Impact of the Civil Liability Legislation on Fundamental Policies and Principles of the Common Law of Negligence' (2006) 14(3) Torts Law Journal 268, 268.

${ }^{78}$ David John Kearney, Public Liability Insurance - The Impact of the New Legislative Framework (2003) Wotton \& Kearney <www.wottonkearney.com.au/ downloads/legreforms.pdf $>$ at 25 November 2006,18 .

${ }^{79}$ Coonan, above n 51, 9.

${ }^{80}$ Keeler, above n 34, 51.

${ }^{81}$ Coonan, above n 51, 8.
} 
Counterpoint:

While much of this 'insurance crisis' relates to the functioning of the insurance industry itself, the law of negligence has been implicated by the insurance industry pointing to the perceived uncertainties in the application of the common law, increases in the number of insurance claims, and most disturbingly, an increase in extremely large damages awards. (Cappa, Forrest, Hinchy, and Nase) ${ }^{82}$

The truth is that the current crisis has primarily arisen out of a variety of complex commercial and economic factors.(Cashman) ${ }^{83}$

[T] he current situation in relation to the affordability and availability of public liability insurance and medical indemnity insurance, is principally caused by factors unrelated to the legal system.(Heinrich) ${ }^{84}$

The Institute of Actuaries of Australia concluded the 'insurance crisis' was the direct result of industry mismanagement, including pricing to attract premium income rather than to meet costs, and gross manipulation of case estimates (McCarthy P, IAA, 2001).(Gordon) $)^{85}$

Each crisis brought with it responses that centred very largely on legal change: for example, in South Australia the enduring consequences of the crisis of the 1980s included the abolition of common law claims by employees against employers and a regime of restrictions on the award and levels of damages in motor vehicle third party cases. So it was no surprise that remedial action for the crisis of 2001-2002 should also focus on the law of negligence. It was the most attractive area for liability insurers to focus on (rather than, say, anything that might suggest there had been deficiencies in managing their own businesses)...(Keeler $)^{86}$

[T] he problem that now exists is the consequence of -

\footnotetext{
${ }^{82}$ Cappa, Forrest, Hinchy, and Nase, above n 21, 212.

${ }^{83}$ Peter Cashman, 'Tort Reform and the Medical Indemnity 'Crisis" (2002) 25(3)

University of New South Wales Law Journal 888, 894.

${ }^{84}$ Heinrich, above n 61, 5.

${ }^{85}$ Gordon, above n 55, 4.

${ }^{86}$ Keeler, above n 34, 48-49.
} 
Continuing increases in claims costs for personal injury claims (a 20 or 30 year phenomenon that currently shows no signs of abating)

An insurance market dominated by defensive pricing and underwriting by insurers (a recent phenomenon and part of a severe insurance market cycle).(Pearson and Atkins) ${ }^{87}$

A gradual real increase in claims costs over a twenty year period may well be, at least in part, the price of medical and economic advances which have benefited the Australian community. ... [C]urrent claim costs have been compared to comparable figures from the late seventies or early eighties with the implication that the law had got it right then and what was right then is right now. That is not necessarily the case at all, our community has changed considerably in that time in terms of prosperity, education and technology (Heinrich). ${ }^{88}$

\section{A Personal Perspective on the Reform}

This author's fundamental objection to the legislative reform of the tort of negligence is that it has in many regards aspects that are unprincipled in terms of self-evident truths and unalienable rights, to borrow the words from the American Declaration of Independence.

One of the premises of the reform legislation 'went to the heart of the Government's concerns about a litigation culture ${ }^{89}$ as '[i]n the words of the [former New South Wales] Premier, ...Bob Carr... reforms are intended "to wind back this culture of blame". ${ }^{90}$ Davis eloquently summarises this phenomenon as 'a culture in which everyone feels there is no injury without blame, and no blame without a claim. ...[in short] "blame and claim". ${ }^{91}$ Although there has been much debate as to the evidence of such a culture's existence in Australia, this authors submits that such a point is irrelevant for it is a matter of perspective - a culture of blame can equally be positively

\footnotetext{
${ }^{87}$ Estelle Pearson and Geoff Atkins, 'Public Liability Insurance - Analysis for Meeting of Ministers 27 March 2002' (Trowbridge Consulting Limited, 2002), ii.

${ }^{88}$ Heinrich, above n 61, 9 .

${ }^{89}$ NSW Government, 'Response to the Legislative Council General Purpose Standing Committee No. 1 Inquiry Report into Personal Injury Compensation Legislation' (2006), 3.

${ }^{90}$ Clark, Harris and Mclnnes, above n 73, 54.

${ }^{91}$ Davis, above n $38,866$.
} 
characterised as a culture to 'keep the bastards honest' to borrow the popular catchcry of Don Chipp, the founder of the Australian Democrats Party. Furthermore, there can only be blame if a certain party is at fault. The principle of justice gives a party who feels illegally aggrieved by another the right to be heard on the merits of the case. If there is no basis for the party's claim, then the matter can be dealt with by the sanctions for abusing court process. So why does personal injury caused by negligence have to be singled out for extra, special treatment when there is already in place legal deterrence against vexatious actions that may arise from a culture of blame at large?

Therefore based on the aforementioned reason, it is also irrelevant as to whether there is an explosion of litigation, the supposed consequence of a society with a culture of blame. If there really is an explosion of valid personal injury claims based on negligence as the cause of action, then the explosion is just a symptom of the underlying causes which should be the focus of any just, sustainable solution. It may also point to a need for courts to adopt more efficient case management practices or foster greater use of alternative dispute resolution regimes, both of which are supposed to be already in place, if not in progress, in Australia as part of a broader reform of the legal system. On the other hand, if there is an explosion of intentional baseless claims in the same category, then the issue is the sufficiency of the penalties for deterring such claims. As such any culture of blame and explosion of litigation, even if they exist, are at best phenomena rather than causes of the insurance crisis. Indeed, if governments insist on the validity of the 'culture of blame' premise, should they not mandate education and legislation that indoctrinate the whole population to strictly adhere to the biblical teaching of turning the other cheek for such an action is at least principled, consistent and likely to save the society the tremendous cost of having to maintain liability insurance and even the court system?

Another premise which Coonan has espoused in her manifesto is that although ' $[\mathrm{t}] \mathrm{he}$ Australian Consumer and Competition Commission...[has] identified a range of factors impacting on the cost of public liability and professional indemnity insurance... it has been necessary for governments to consider which cost drivers can realistically be contained within the Australian context...[since t] he state of the international reinsurance or investment markets is not a matter that Australian governments can do very much to influence. ${ }^{92}$ Yet it is interesting to note that Trowbridge Consulting in its report prepared for the meeting of Ministers on 27 March 2002 has

${ }^{92}$ Coonan, above n 51,7 . 
listed 10 possible claim cost responses and 13 possible insurance market responses. ${ }^{93}$ But in its report dated May 302002 to the Insurance Issues Working Group of Heads of Treasuries, it has 21 claim cost- and/or lawrelated proposals and 9 insurance market-related proposals out of a total of 35 proposals. ${ }^{94}$ Moreover the insurance market-related proposals are 'soft' and easy on insurers with the hard solutions previously suggested such as '[s]tart a new Government Insurance Office', '[m]ake supply of insurance compulsory for insurers' and '[s]et maximum prices that can apply', simply disappeared in the course of less than three months between the two reports without a word of explanation as to how and why the proposals have been selected out of the possible responses. Perhaps it is because 'our government has no power to dictate to private insurance companies... ${ }^{95}$ as stated by Rod Welford, Queensland's former Attorney-General. But what makes the governments think that they have the power to 'dictate' to the Australian people? Is it because it is simply the law of the jungle with the weaker getting pushed over by the stronger? Or is it because of the laissez-faire political ideology of the Liberal Party that rules the Federal Government? If so, why should it not be laissez-faire with legal rights as well as commercial rights?

Coonan has also mentioned in her paper the 'need to act quickly' and get 'the settings right to ensure the [insurance] market works more effectively. ${ }^{96}$ But where is the urgency of governments and bureaucrats to fix the insurance market when APRA statistics indicate that ' $[\mathrm{t}] \mathrm{he}$ returns [of the insurance industry] in 1998-99 and 1999-2000 were lower than the cash rates ${ }^{97}$ - the two years before HIH's collapse, especially when there has been precedents of insurance crises in Australia? Why have the politicians and bureaucrats not learnt their lessons? Where were the "far-sighted reforms" ${ }^{98}$ as touted by Coonan?

Coonan's most intriguing, if not hypocritical, statements are that on one hand, '[g]overnments are elected to address the concerns of the community', ${ }^{99}$ yet 'relatively speaking, personal injury law provides very generous compensation to a very small proportion of the population at considerable expense to the rest of the community[ and t]here is an

\footnotetext{
${ }^{93}$ Pearson and Atkins, above n 87, iv-v.

${ }^{94}$ Atkins and Pearson, above n 59, viii-ix.

${ }^{95}$ Cappa, Forrest, Hinchy and Nase, above n 21, 215.

${ }^{96}$ Coonan, above n 51, 8-9.

${ }^{97}$ Ibid, 8.

${ }^{98}$ Ibid.

${ }^{99}$ Coonan, above n 51, 7.
} 
overwhelming consumer interest in restoring the balance in a system where, at present, the benefits disproportionately favour the few. ${ }^{100}$ Surely governments are to address the concerns of all communities in the society rather than to suppress a minority for the majority. Her statements are divisive and unwarranted. It is fortunate that those who are injured are a minority in this country and hopefully is going to remain so for who wants their country to be a nation of the disabled. Relative to what and whose standard is compensation "very generous" and how are "the benefits disproportionate"? It is a dangerous argument being mounted by Coonan for if it is valid then what is to stop governments from applying the same to legislate preventing senior citizens from accessing Medicare if they are above a certain age on the ground that they cost the society too much relative to the size of their group and thus should rely on their own means to pay for healthcare services, or withholding life support medical service to injured people in coma unless that person can afford such service because of health budget constraints?

Furthermore where is the common sense, let alone principle and consistency, when the second Trowbridge Consulting report then forms the basis of the terms of reference for the Ipp panel? Is it not ironic that the tort reform is based on a blueprint developed by actuaries? It is even more bizarre that the legislative changes of a tort reform are wide reaching to the extent that they apply "regardless of whether the claim for damages is brought in tort, in contract, under statute or otherwise". ${ }^{101}$

There are undoubtedly many aspects of the reform which do not inspire confidence but in this author's opinion none more so when Coonan, the leading advocate of the reform, does not seem to be able to get simple facts right. According to her same article, 'bodily injury claims have been increasing Australia-wide on average by 10 per cent per annum over the past decade. ${ }^{, 102}$ Yet a search of the second Trowbridge Consulting report which is her cited source does not reveal any such information but rather that 'the average bodily injury claim size has increased at $10 \%$ per annum, ${ }^{103}$ with the same information repeated in 'Table 2 - Fitted Average Size - Bodily Injury'

\footnotetext{
${ }^{100}$ Ibid, 9.

${ }^{101}$ Kearney, above n 78, 6. Subsections 28C(2) and (3) of the Wrongs Act 1958 (Vic) are similar in effect to sub-s 11A(2) of the Civil Liability Act 2002 (NSW) cited by Kearney.

${ }^{102}$ Coonan, above n 51, 8 .

${ }^{103}$ Atkins and Pearson, above n 59, 69.
} 
of the same report. ${ }^{104}$ This ' 10 per cent' figure is also stated in the first Trowbridge Consulting report. ${ }^{105}$ It is a big difference between the number of claims and the average claim size. This error is particularly peculiar since she has not cited any pinpoint reference in her relevant footnote.

This author cannot help but agree with Feldthusen that, insofar as the tort reform is concerned, it is naïve to assume 'that law reform issues and solutions find their way on to the public agenda more or less by magic because (a) an important social problem exists; and (b) the proposed solutions are thought to address the problem...[for $t$ ]he public agenda is set and manipulated by organised interest groups[, and e]lected governments adopt policies that maximise their chances of re-election[ and hence i]dentifying the power and the political pressure points will often, clarify what appear to be irrational definitions of public problems and incoherent solutions. ${ }^{106}$

\section{Analysis of the CuRRent General Damages Regime IN VICTORIA}

\section{A Overview of the case against the existing regime}

Given this author's unfavourable evaluation of the reform as a whole, it follows that a similar view would be reached with the changes concerning general damages. With the three aims of "legislative "reform" of the common law tort of negligence... [being] to reduce the cost of legal proceedings; reduce the number of frivolous claims for minor injuries; and to cap the size of large claims, ${ }^{107}$ a number of unprincipled, inconsistent consequences arise from existing laws related primarily to threshold, cap and assessment of noneconomic loss. It is paradoxical for John Lenders, the Finance Minister of Victoria to have said on record that ' $[\mathrm{t}]$ hese reforms have been a success. They were designed to restore confidence to the insurance industry and to the people's ability to sue. ${ }^{108}$ Whilst it is obvious that the reform has been a

\footnotetext{
${ }^{104}$ Ibid, 74.

${ }^{105}$ Pearson and Atkins, above $\mathrm{n} 87$, ii.

${ }^{106}$ Feldthusen, above n 2, 855-856.

${ }^{107}$ Cappa, Forrest, Hinchy and Nase, above n 21, 214.

${ }^{108}$ ABC Television, 'Are the government's insurance reforms leaving legitimate victims without compensation?', Stateline, 11 Feburary 2005 $<$ http://www.abc.net.au/stateline/vic/content/2005/s1301173.htm $>$ at 24 November 2006 .
} 
success for the insurance industry, it is not clear how his comment on the reform restoring confidence to the people's ability to sue bears any resemblance to reality.

An important point on principle to note is that as Bob Gotterson has said, "It's also worth noting that what may be a "trivial" amount to one person is not necessarily "trivial" to another. ${ }^{109}$ But fundamentally the questions which Victorians and majority of Australians have been confronted with since the beginning of the reform are:

Should there be full compensation for the loss sustained or should there be partial compensation pursuant to statutory limits? Is there a sound case for the introduction of thresholds and/or caps on the damages recoverable for the loss...? ${ }^{110}$

One school of thought is that '[m]oney by definition cannot restore nonpecuniary loss[ and hence s] ome would argue for the outright abolition of non-pecuniary damages. ${ }^{, 111}$ It is cited as support for the contention that '[m]ost compensation schemes [in Canada] ignore or limit recovery under this head" 112 and "pain and suffering type harms are largely ignored in the US by a wide range of other compensation mechanisms. ${ }^{113}$

On the other hand, this author believes that 'restrictions on the right to recover full compensation for loss...[are] entirely unsupported by principle[ as w]hatever the nature of the threshold and/or cap introduced it will be utterly arbitrary and artificial[ and]...plaintiffs are no longer treated as individuals but as a homogenous group. ${ }^{114}$ As a result, '[a]ttention shifts from what has actually been lost by the plaintiff injured to what is thought by the government of the day to be reasonable by reference to some notional standard. ${ }^{115}$ In the final analysis, "[a]rbitrary and artificial limits are not, of course, unknown in the law, but they should be avoided wherever possible. Certainly they should be avoided where the basis for their introduction is highly questionable and it is clear that they will operate in an unfair or

\footnotetext{
${ }^{109}$ Law Council of Australia, above n 12, Media release.

${ }^{110}$ Mullany, above $\mathrm{n} 1,878$.

${ }^{111}$ Feldthusen, above n 2, 857.

${ }^{112}$ Ibid.

${ }^{113}$ Sugarman, above n 3, 513.

${ }^{114}$ Mullany, above n 1, 878.

${ }^{115}$ Ibid.
} 
prejudicial manner. ${ }^{116}$ It is an understatement by Chief Justice Spigelman of New South Wales, that 'the introduction of caps on recovery and thresholds before recovery - an underwriter driven, not a principled change - has led to considerable controversy. ${ }^{117}$

It is interesting to note that Sugarman's suggestions on damages law reform are remarkably similar to those implemented by a large number of Australian governments. His primary justifications are also very much akin to those used by the Federal Government in that:

Potential social gains of ridding the system of a giant share of current claims are very large[ with]... prospect of large savings in legal costs and payouts, as well as the reduced burden on the administration of the judicial system[ and]...prospect of overturning the widespread...social norm that suing somebody else when you are hurt in an accident is what everyone does and what you are culturally expected to $\mathrm{do}^{118}$ [, and]...[a] much greater share of the damages awarded in tort would go to fill genuine need, and more of the total payout would go to the more seriously injured. ${ }^{119}$

In essence his argument is based on American pragmatism with the idea that the means are justifiable by the end. It is lamentable that the Australian legal system has imported such values from the United States of America rather than commendable features of her legal system. But even at a pragmatic level, his contention is shallow to the extent that:

The introduction of thresholds does not remove the cost of injury to the community. What they do is cause the cost to be shifted from the wrongdoer to the injured person and the community at large. The community suffers, not only because access to justice is denied to many, but because of the removal of incentives to maintain high levels of safety to avoid injury and because of increased taxation necessary to fund to hospital, medical and social welfare expenses no

\footnotetext{
${ }^{116}$ Ibid.

${ }^{117}$ Chief Justice James Spigelman, 'The New Liability Structure in Australia' (Speech delivered at the Swiss Re Liability Conference, Sydney, 14 September 2004).

${ }^{118}$ Sugarman, above n 3, 516.

${ }^{119}$ Ibid, 524.
} 
longer met by tortfeasors. Caps on damages give rise to similar problems. ${ }^{120}$

Indeed as an example of the phenomenon predicted by Mullany, it is claimed that ' $[t]$ he costs of caring for injured people have shifted from insurers to the public heath system, with a $\$ 12$ million increase in Medicare costs in NSW since the changes to injury compensation laws. ${ }^{121}$ It would be interesting to compare this amount with the total increase in public and professional liability insurance premium in New South Wales during the crisis to see whether it may actually be more economical for government to subsidise the full extent of the increase on a one-off basis to help businesses and organisations to get over the crisis instead of implementing the reform.

Another instance of the arbitrariness of utilitarianism in action in the reform is the entitlement to interest on general damages which has been completely removed in a number of jurisdictions albeit not Victoria. According to the Ipp Panel:

The principle underlying awards of pre-judgement interest is that the plaintiff's entitlement to be compensated arise at the date the cause of action is complete. If the plaintiff does not actually receive the compensation until some time later, she has been 'kept out of the' money to which she is entitled, and so should be awarded interest to compensate her for not having had the use of the money ...damages for pre-judgement general damages are calculated according to the value of money at the date of judgement. This effectively eliminates the need for compensation for being 'out of the money'. ${ }^{122}$

If interest is effectively imputed into the award amount at the judgment date, it means that victims are entitled to interest which is simply not separately itemised, then why does interest on general damages have to be abolished?

An even more illogical reasoning that seems like shedding crocodiles' tears on the part of the Ipp Panel, is that:

\footnotetext{
${ }^{120}$ Mullany, above n 1, 880.

${ }^{121}$ A Fair Go For Injured People, Personal Injury Compensation - Background Briefing Paper $<$ http://www.faircompensation.com.au/docs/briefing_paper.pdf $>$ at 24 November 2006.

${ }^{122}$ Chris Latham and Michael Playford, 'Report to the Insurance Issues Working Group of Heads of Treasuries - Actuarial assessment of the recommendations of the Ipp Report' (PricewaterhouseCoopers Actuarial Pty Ltd, 2002), 25.
} 
There is some irony in the introduction of reforms targeting proportionate liability. The Ipp Report declined to recommend its introduction in personal injury cases on the grounds that there was a risk that plaintiffs would not fully recover their losses. ${ }^{123}$

If governments are so concerned about the mere risk of victims not fully recovering their losses, how do they look the electorate in the eye and tell them with a straight face about the imposition of thresholds and caps which are measures that not only realise the very risk that governments seem to care so much about but fly in the face of the principle of full restitution.

\section{B General damages thresholds}

Of all the legislative changes concerning general damages, none is more controversial than the imposition of thresholds, and rightly so. The raison d'être for thresholds is as follows:

Claims for general damages have traditionally accounted for about 45 per cent of the total cost of public liability injury claims in the $\$ 20,000$ - $\$ 100,000$ bracket[ and so]...[i]ntroducing thresholds, it was thought, would significantly reduce the number of smaller claims that many believed were behind the hike in insurance premiums. ${ }^{124}$

[Accordingly t] Negligence...recommended imposing a threshold for general damages based on 15 per cent of a most extreme case... saying that such a threshold was 'an effective and appropriate way of significantly reducing the number and cost of smaller claims'. ${ }^{125}$

The Federal Government's justification seems to lie with the first Trowbridge Consulting report in which it is stated that:

Introducing a threshold/deductible for general damages equivalent to, say, $\$ 20,000$ would be unlikely to have the potential to reduce claims costs by any more than $10 \%$ and for any savings to be sustainable would need to -

\footnotetext{
${ }^{123}$ Morgan and Skinner, above n 24, 7.

${ }^{124}$ Law Council of Australia, above n 15, 1.

${ }^{125}$ Ditto.
} 
- prevent erosion of the deductible itself (as occurred in the NSW scheme) through increasing general damages awards for more minor injuries

- prevent leakage of compensation from general damages to future earning capacity (economic loss buffers). ${ }^{126}$

According to the second Trowbridge Consulting report, '[f]rom work done in NSW CTP, we believe a $10 \%$ permanent impairment threshold may equate roughly to a $\$ 40,000$ to $\$ 50,000$ general damages amount (although it may be lower in Victoria). ${ }^{127}$ Therefore it would seem from Table 1 that the Victorian threshold equates to about $\mathrm{A} \$ 20,000$ in monetary terms and the potential effect on claims costs would be comparatively low in relation to the rise in insurance premium in the wake of the crisis.

Gotterson also asserts that:

The argument for imposing thresholds is based on a belief that if we can limit the number of smaller claims, then insurance premiums will drop. But if claim numbers drop, there is no guarantee that insurers will pass on their cost savings in the form of reduced premiums to organisations or individuals... ${ }^{128}$

His view is shared by the Law Council which 'does not believe there is satisfactory evidence that restricting the availability of damages for noneconomic loss will reduce insurance premiums." 129 At the same time "underwriters are cautious of reducing premiums...while their liability is unclear under policies with very long liability tails. ${ }^{130}$ But as far as this author is concerned, even if insurers reduce their premium by the full 10 per cent as predicted by Trowbridge Consulting under the best case scenario, such 'benefit' in no way validates thresholds which are objectionable at both conceptual and operational levels.

At the conceptual level, thresholds are unethical for the following reasons:

\footnotetext{
${ }^{126}$ Pearson and Atkins, above n 87, 53.

${ }^{127}$ Atkins and Pearson, above n 59, 17.

${ }^{128}$ Law Council of Australia, above n 12, Editorial.

${ }^{129}$ Ibid, Backgrounder - Damages for Noneconomic Loss and Thresholds.

${ }^{130}$ Pelletier, above n 39.
} 
To rule out recovery for non-economic loss fails to appropriately recognise that personal capacities (like the ability to run and see) and mental equilibrium lie at the core of what it is to be human. To many victims of negligence the component of their award that compensates them for pain and suffering and loss of enjoyment of life is of the most significance.(Law Council of Australia) ${ }^{131}$

Thresholds are used to arbitrarily determine whether a person should be compensated for their injuries, without any regard to the impact of an injury on a person's way of life. ... This is compounded by the inconsistencies between the different thresholds in personal injury schemes, which are nonsensical and contrary to community expectations.(A Fair Go For Injured People) ${ }^{132}$

Thresholds do not distinguish between the personal circumstances of claimants. For example, they do not differentiate between the loss of a finger for a concert pianist as compared to an office clerk (Law Council of Australia). ${ }^{133}$

The most pernicious feature of the legislation is the assumption that people with an injury that is less than [a threshold] are suffering from only trivial or superficial conditions that do not deserve compensation.(McGarvie and Maynard) ${ }^{134}$

[Ultimately t]hresholds arbitrarily remove common law rights.(Law Council of Australia) $)^{135}$

At an operational level, thresholds produce a number of inequitable consequences:

Thresholds meant that a certain level of negligence becomes free from financial consequence to the person who is at fault. This risks causing safety standards to decrease. (Law Council of Australia) $)^{136}$

\footnotetext{
${ }^{131}$ Law Council of Australia, above n 129.

${ }^{132}$ A Fair Go For Injured People, above n 121.

${ }^{133}$ Law Council of Australia, above n 15.

${ }^{134}$ Michael McGarvie and Lisa Maynard, 'Australian Product Liability - The Demise of the Everyday Claim' (2006) (73) Precedent 8, 12

${ }^{135}$ Law Council of Australia, above n 129.

${ }^{136}$ Law Council of Australia, above n 15.
} 
[T]hresholds allow a certain level of negligence to be "acceptable". But negligence should never be acceptable[ for]... allowing lapses to occur in "trivial" cases could lead to catastrophic accidents occurring down the track. (Law Council of Australia) ${ }^{137}$

Thresholds diminish the incentive for risk management. (Law Council of Australia) $)^{138}$

[R]eductions on eligibility to compensation...do nothing to improve the taking of personal responsibility by persons at risk of having accidents. They simply relieve costs for defendants - in fact reduce the need for them to take responsibility. (North) $)^{139}$

Thresholds not only eliminate so-called "trivial" claims, they remove the entitlement to compensation for all claims below the threshold. Depending on the level of threshold, many of these claims would not be considered 'trivial'. (Law Council of Australia) ${ }^{140}$

Thresholds on non-economic loss have a greater impact on stay at home mothers and fathers, the elderly, unemployed and children. For people such as these whose claims for economic loss (that is, earning capacity) are usually lower than for full-time workers, the loss of non-economic damages can make it practically impossible to bring a claim at all, even if theoretically there would be an entitlement to be reimbursed for medical expenses. (Law Council of Australia) ${ }^{141}$

[T]he exclusion of pain and suffering compensation for persons under a threshold (such as a permanent impairment level, or a percentage of the worst case), can effectively end (by making it uncommercial to pursue) a claim for persons whose claims are largely for non-economic loss[ such as one]...involving less serious injuries (and so not requiring large medical or future care costs awards), [or] by people who are not in the paid workforce (and so do not have economic loss). (Heinrich) ${ }^{142}$

${ }^{137}$ Law Council of Australia, above n 21, Sample Letter to an MP.

${ }^{138}$ Law Council of Australia, above n 129.

${ }^{139}$ North, above n 32, 9.

${ }^{140}$ Law Council of Australia, above $n 15$.

${ }^{141}$ Law Council of Australia, above n 129.

${ }^{142}$ Heinrich, above n 61, 11. 
Thresholds also discourage rehabilitation and recovery. This is because, under thresholds, it is in the interest of the injured person to remain impaired rather than take steps, such as treatment or rehabilitation, to improve. (Law Council of Australia) ${ }^{143}$

Insurers will chose to use the impairment thresholds in borderline cases to negotiate a discounted settlement. (Radloff, Saxton and Triantopoulos) $)^{144}$

Thresholds have a cost shifting effect in that expenses incurred by the injured person are shifted in part (or in whole) from the negligent person onto the injured person, their family and/or the entire community via the health and social security systems. Accordingly, cost shifting can only save the community an expense if the consequences of the injury are borne entirely by the individual injured. To the extent any of the cost leaks to the social security and health systems, then the effect is to shift costs from the insurance pool to the public purse. It is only fair to expect that the full burden of liability and cost of injury be borne by the one responsible for the injury (generally through their public liability insurance policy). The burden should not be subsidised by the community or the accident victim. To do so, in the Law Council's view, offends a deeply held sense of fairness in the Australian community, which is reflected in the common law, namely: that the wrongdoer should pay for his or her acts or omissions. (Law Council of Australia) ${ }^{145}$

To top it off, given all the above unjust outcomes, there is 'no suggestion that the introduction of a threshold be accompanied with a counterbalancing benefit scheme'. ${ }^{146}$

Despite the overwhelming reasons listed above for rejecting thresholds, Sugarman has put forward some scenarios that favour imposing thresholds such as:

Victims have "no ongoing pain and suffering" or what they feel may "have been very temporary". 147

\footnotetext{
${ }^{143}$ Law Council of Australia, above n 15.

${ }^{144}$ Radloff, Saxton and Triantopoulos, above n 27, 8.

${ }^{145}$ Law Council of Australia, above n 129.

${ }^{146}$ Mullany, above n 1, 879 .

${ }^{147}$ Sugarman, above n 3, 515.
} 
Victims exploit the "nuisance value" in terms of "defendants" needs to get the claims off their books. ${ }^{148}$

[D]evious victims...[run] up unneeded care costs, to manufacture ailments... ${ }^{149}$

He goes on to suggest that 'combining a threshold on pain and suffering awards with a reversal of the collateral source rule means that the tort system would shift its focus towards the more seriously injured. ${ }^{150}$ Again, this author finds his contingent claims to be unpersuasive to say the least. First, however transient is the pain and suffering experienced, it does not alter the fact that a victim has suffered and therefore is entitled to general damages. Secondly, 'nuisance value' is not universal and from the perspective of a victim, it may well be argued that the real 'nuisance value' in the first place is the need for a victim to pursue the claim for general damages after already having been injured. But ultimately this notion of 'nuisance value' is of little bearing, for the issue is whether the defendant is at fault and if so then the 'nuisance value' may be considered as part of the penalty for the wrongdoing. Thirdly, any potential or actual abuse of a system or process does not excuse 'throwing out the baby with the bath water' as the saying goes. Does it follow that because a legal system is open to abuse, citizens are not entitled to pursue their legal rights? Finally, a case based on sugar-coated utilitarianism does not answer the questions of by whom and what is one to determine the degree of seriousness in injuries and how such measure has any relevance to the award and assessment of general damages.

\section{Assessment of general damages}

As shown by Table 1, Victoria and a number of states and territories have adopted the degree of impairment as a proxy of the extent of non-economic loss and thus the amount of general damages to be awarded. Of course the most unprincipled element of such an approach is that there is no obvious logical connection between the first two aforementioned variables to warrant the former being an approximation of the latter.

The injury assessment approach is also often criticised for being invalid since " $[t]$ o assess an injured person's level of "whole person impairment" and their

\footnotetext{
${ }^{148}$ Ibid, 516.

${ }^{149}$ Ibid.

${ }^{150}$ Ibid.
} 
entitlement to fair compensation, the...Government adopted the American Medical Association "Guides to the Evaluation of Permanent Impairment" ('AMA Guides') [and t]his was despite advice in "the Guides" themselves that the "criteria should not be used to make financial awards or direct estimates of disabilities". ${ }^{151}$ The uncertainty in assessment results is also a bane in using the AMA Guides as elaborated herewith by way of examples:

The loss of a fallopian tube in a pre-menopausal woman is assessed between $0 \%$ and $15 \%$ whole person impairment. Whether such an injury is above or below 5\% will be unavoidably arbitrary as the Guides offer little help to the doctor making the assessment. Clearly, the insufficiency of the Guides was recognised by the government, as they have made some exceptions for cases involving loss of a breast or foetus. If the Guides were adequate..., such exceptions would not be necessary. Nevertheless, the exceptions have brought their own arbitrariness: a mother may be compensated if her baby is stillborn as a result of negligence but not if her baby was born alive but dies a few days later as a result of mismanagement of the labour. ${ }^{152}$

Additionally there are a number of other anomalies with the whole injury assessment approach:

[An] unfortunate effect of impairment thresholds is the inability when assessing impairment to take any account of the subjective impact of an injury on a person's way of life. ${ }^{153}$

[In contrast, as an example,] permanent pain and suffering is conventionally determined by taking into account the future life expectancy of the victim - ie, the number of years of suffering that lie ahead. ${ }^{154}$

Some examples of injuries that would not qualify for non-economic loss damages under the new regime will be: Loss of taste 3 per cent (AMA4) ... Loss of sense of smell 3 per cent (AMA4) ${ }^{155}$

\footnotetext{
${ }^{151}$ A Fair Go For Injured People, above n 121.

${ }^{152}$ Kathryn Booth and Jacob Varghese, 'The Rush to Law Reform in Personal

Injuries' (2003) 28(5) Alternative Law Journal 210, 210-211.

${ }^{153}$ Bugg, above n 5, 10.

${ }^{154}$ Sugarman, above n 3, 514.

${ }^{155}$ Lombard and McGarvie, above n 31, 4.
} 
[P]eople most disadvantaged by impairment thresholds are those who suffer serious injury as a result of negligence, but have no permanent impairment. This is because the Guides only recognise injuries that are permanent. Yet surgical errors... which may require multiple operations to repair, extensive hospitalisation and long-term debilitation, will not always result in a permanent impairment. Other cases may involve a serious departure from the standard of care but will provide limited legal redress for the patient involved... ${ }^{156}$

Most of the everyday injuries that arise out of the use of defective household and domestic equipment are not catastrophic. In fact, they don't often produce injuries which would fall into the category of $15 \%$ of a most extreme case. ${ }^{157}$

The Committee received a submission that asserted that recent amendments made to the Wrongs Act 1958 ('Act'), may discriminate against people with psychiatric disabilities. ... The threshold level for psychiatric impairment is 10 per cent, while the threshold for other types of impairment is 5 per cent. ... The Committee notes that there is no reference to the reason for the differential treatment of different types of injury in the Second Reading Speech. The Committee notes that there are also different threshold requirements for non-economic loss between psychiatric and physical injuries in the Accident Compensation Act 1985, but that there is no distinction in the Transport Accident Act $1986 .{ }^{158}$

$[\mathrm{U}]$ nless a parent can show an ongoing psychiatric impairment of greater than $10 \%$, an extremely high threshold, no claim will arise from the death of a child, no matter how serious the negligence. ${ }^{159}$

$[\mathrm{P}]$ sychiatric and psychological injury arising as a consequence of the physical injury is excluded from the assessment. This is generally known as 'secondary psychological injury'. ${ }^{160}$

\footnotetext{
${ }^{156}$ Booth and Varghese, above n 152, 211.

${ }^{157}$ McGarvie and Maynard, above n 134, 11.

${ }^{158}$ Scrutiny of Acts and Regulations Committee, Parliament of Victoria, Discrimination in the Law: Inquiry under Section 207 of the Equal Opportunity Act 1995 - Interim Report (2005), 15-16.

${ }^{159}$ Booth and Varghese, above n 152, 211.

${ }^{160}$ Lombard and McGarvie, above n 31, 3.
} 
This is contrasted with direct psychological injury which is included in the assessment. This author contends that such distinction is unjust where the secondary psychological injury is caused but for the physical injury.

A further criticism is that there is "[a] lack of accountability... because judgements made about the level of impairment are made by bureaucratic authorities and their doctors [and as a result]... there is limited scope to test these findings or to take into account the views of treating doctors or specialists (.i.e. doctors who have in-depth knowledge of their patient's degree of impairment and trauma). ${ }^{161}$ This is often the case with injury assessment for motor vehicle and work accidents, which is administered by individual statutory authorities. The same issue occurs with public liability and medical negligence cases in Victoria by virtue of the statutory requirements that only certain medical practitioners can conduct assessments and reassessments can only be performed by medical panels, with no right of appeal, as described in Section V above. It is said that this situation is made worse in medical negligence cases as '[p]laintiff lawyers already have a difficult time finding doctors prepared to criticise the performance of their peers[ and g]iven the pervasive anti-litigation attitude of the medical profession, bias and the perception of bias is inevitable when medical panels assess injuries in medical negligence claims'. ${ }^{162}$

\section{Caps on general damages}

As explained above in sub-section A of this Part, caps are just as unprincipled as thresholds. However, it is the Federal Government's rationale for its adoption that portrays a blatant effort to not only justify the means the end but to indeed cut off the nose to spite the face.

It is acknowledged by the insurance industry and actuaries that:

Large damages awards are not a significant cause of rising premiums and that, consequently, capping awards will not solve that problem. ${ }^{163}$

It is clear from the material and from our general knowledge of large awards for personal injury claims that a cap on general damages is unlikely to have any material impact on current claims costs unless

\footnotetext{
${ }^{161}$ A Fair Go For Injured People, above n 121.

${ }^{162}$ Booth and Varghese, above n 152, 211.

${ }^{163}$ Mullany, above n 1, 881.
} 
set at a very low level (say $\$ 100,000$ ) and accompanied by proportionate scaling below this level... ${ }^{164}$

Despite such opinions the Federal Government champions for the introduction of caps for they 'are not, in themselves, cost reduction measures but are designed to improve greater stability and enable consistent calculation of general damages amounts below the cap..."165 Thus the 'major direct effect of any cap... is to cut back on what the most seriously injured victims can be awarded [in order to]... have the effect of forcing a downward adjustment of pain and suffering awards... throughout the full range of harms..., 166

A cascading effect from the imposition of caps and thresholds is the scale in between the two ends, which although is not applicable to Victoria, is nonetheless worth mentioning as a number of other jurisdictions have implemented a sliding scale regime which is arbitrary when compared with a proportional scale. It is contended that:

A strictly proportional scale is, in our view, not appropriate. ... If a proportional scale is adopted there is likely to be significant pressure placed upon the threshold by claimants who are at a level slightly below the $15 \%$ mark. ... This is because benefits are significant just above the threshold, creating an incentive for claimants to inflate the severity of their claim. This "bracket creep" is likely to erode the threshold. Bracket creep is less likely under the sliding scale as only quite small benefits are available just above the threshold. ${ }^{167}$

Another inconsistency identified is that:

While damages for non-economic losses for personal injury have been capped, there is currently no statutory cap on the amount that can be awarded for such losses in defamation law. ${ }^{168}$

Whilst any cap amount is subjective by nature, there is further concern regarding its adequacy. At least in relation to personal injury in product

\footnotetext{
${ }^{164}$ Pearson and Atkins, above n 87, 53.

${ }^{165}$ Coonan, above $\mathrm{n} 13,83$.

166 Sugarman, above n 3, 514.

${ }^{167}$ Latham and Playford, above n 122, 16-17.

${ }^{168}$ Graycar, above $n$ 9,5.
} 
liability cases (but there is no reason why the same issue is irrelevant to other negligence liability areas), it is asserted that:

The least obvious vice in this limit on damages is the statutory maximum. In 15 or 20 years' time, that maximum will be unacceptably low compared to the then community standards for damages for pain and suffering being awarded by courts in catastrophic cases. ... Despite the existence of CPI increases under the TPA, significant erosion of the remedy will tragically compound the most extreme injuries suffered in defective product accidents within a decade or two. ${ }^{169}$

It is perhaps for the above reasons that the Holy Grail of the reform has not been attained for according to the Ipp Panel:

In no area is the law more diverse, and (we are convinced) in no area is conformity more desirable, than in regard to the quantum of damages. ${ }^{170}$

It is also for the above reasons that this author cannot agree with Feldthusen's comment that 'The suggested cap on general damages is comparable to the common law cap adopted in Canada 25 years ago. On the whole, these suggestions are sensible'. ${ }^{171}$ Just because another country has capped its general damages award does not make the implementation in Australia of the same any more principled.

\section{E Implications for product liability on personal injuries}

This author has already mentioned in Section VIII above the absurdity of the changes of tort reform going beyond the law of negligence. The changes affected by the Federal Government to the Trade Practices Act 1974 (Cth) represent a concrete example of the desperateness of the reform. As Boyd has said:

\footnotetext{
${ }^{169}$ McGarvie and Maynard, above n 134, 12.

${ }^{170}$ Guy Boyd, 'Personal Injuries Law Reform: An Unintended Effect on Product Liability Claims?' (2003) 11(3) Torts Law Journal 262, 263.

${ }^{171}$ Feldthusen, above n 2, 857.
} 
A claim for damages for personal injury under the TPA is not a claim for damages for personal injury resulting from negligence. The concepts of negligence do not equate with the elements of the statutory causes of action under the TPA. ... Despite the panel's reference to 'negligently caused', the panel clearly meant to express its desire to avoid disparity in outcomes between negligence and other causes of action such as those based on the TPA... ${ }^{172}$

The unjust outcomes of the changes in this area of the law are:

Destruction, of real consumer rights for small -to medium-sized claims... ${ }^{173}$

Effectively, it creates two classes under the TPA. Business can obtain remedies under the TPA fully for all economic loss, whilst consumers are limited if they suffer personal injury or death as a result of improper conduct. ${ }^{174}$

It is yet another example of the reform being cutting the nose to spite the face for the ad hoc changes plastered to the Trade Practices Act 1974 (Cth) have undone the progress made in consumer protection. This is because:

In Victoria, some have been advised to consider negligence actions under the new Wrongs Act. But ... [a]n action in negligence would mean not relying on the more simplified strict liability provisions of Part VA of the TPA. ... It would also mean that plaintiffs would have to return to the bad old days of a paper chase, trying to identify the supplier, importer, manufacturer, retailer or another link in the production-and-supply chain that might be said to have acted negligently in producing the defective product. The consumer would then have to make the difficult and risky choice of identifying who in the supply line is blameworthy and whom to sue. ... The unfair balance tipped against injured individuals by the product liability laws that pre-existed Part VA in 1992 will return if most everyday

\footnotetext{
${ }^{172}$ Boyd, above n 170, 264.

${ }^{173}$ McGarvie and Maynard, above n 134, 8.

${ }^{174}$ Law Council of Australia, The Trade Practices Act and the Ipp report (2004) $<$ http://www.lawcouncil.asn.au/get/publications/2404048712.pdf $>$ at 25 November 2006 .
} 
consumer injuries can be dealt with only in the common law courts rather than under the TPA. ${ }^{175}$

\section{CONCLUSION}

The overall effect of the existing regime for individuals is, in a nutshell, unfair for:

Many genuine victims of negligence, who have suffered personal injury, are uncompensated or are not being adequately compensated because of the thresholds and caps on damages that were established. ${ }^{176}$

Claimants can be left in a position where, because of the reduction in entitlement for pain and suffering compensation, it is not economically practical for them to pursue a claim, even if at law they would be entitled to compensation for economic loss or medical expenses. That is why...their right to claim for medical expenses and economic loss can be illusory. ${ }^{177}$

If the injured person went to a public hospital, or if he or she was treated on a weekend, there would be no other recoverable costs such as medical expenses or lost wages. ${ }^{178}$

Although economic loss may still be claimed, few plaintiffs will be willing to proceed with litigation unless there is a real prospect for general damages or economic costs are very high. ${ }^{179}$

It does mean that some people who are quite seriously injured are not able to sue at all. More than any other factor I envisage this restriction will be seen as much too restrictive. ${ }^{180}$

At a community level, the effect of reform is also said to be negative for:

\footnotetext{
${ }^{175}$ McGarvie and Maynard, above n 134, 12-13.

${ }^{176}$ Pelletier, above $\mathrm{n} 39$.

${ }^{177}$ North, above n $32,8$.

${ }^{178}$ Caspar Conde, 'The Foresight Saga - Risk, Litigiousness and Negligence Law

Reforms' (2004) 20(3) Policy 28, 31.

${ }^{179}$ Booth and Jacob Varghese, above n 152, 210.

${ }^{180}$ Spigelman, above n 117.
} 
The community's sense of the coherence and the value of the law is diminished by inconsistency between underwriter-driven liability schemes. ... [and] legislated thresholds for the award of damages which operate to exclude claims for serious injury devalue our common right to personal security. ${ }^{181}$

Therefore this author finds the following quotation a bemusing yet fitting verdict on the Victorian reform:

$[\mathrm{T}]$ he term tort reform implies that caps and other limitations on injured plaintiff's recovery improve the functioning of the...civil justice system. In reality, applying the word reform to those restrictions is as misleading as referring to nuclear weapons as 'peace-keepers'. ${ }^{182}$

TABLE 1: CuRRENT LegisLATIVE FrameWORK ON THE AWARD OF GENERAL DAMAGES ACROSS AUSTRALIA

\begin{tabular}{|l|l|l|l|}
\hline Elements & \multicolumn{1}{|c|}{ Cth } & \multicolumn{1}{|c|}{ Vic } & \multicolumn{1}{|c|}{ NSW } \\
\hline Name of the & Trade Practices & $\bullet$ & Wrongs and \\
Act(s) & Civil Liability Act & Other Acts & 2002 \\
& (Personal Injuries & (Public & \\
& 2004 Death) Act & Liability & \\
& Trade Practices & Reform) Act & \\
& Amendment & 2002 & \\
& (Personal Injuries & Wrongs and & \\
& and Death) Act & Limitation of & \\
& 2006 & Actions Acts & \\
& & (Insurance & \\
& & Reform) Act & \\
& & 2003 & \\
& & A significant injury & 15 per cent of a \\
& & of the following: & most extreme case \\
& & whole person & \\
\hline Threshold & 15 per cent of a &
\end{tabular}

${ }^{181}$ Submission to the Legislative Council Standing Committee, Parliament of New South Wales, Sydney, 10 March 2005, 3.2.5.

${ }^{182}$ Cappa, Forrest, Hinchy and Nase, above n, 215. 


\begin{tabular}{|c|c|c|c|}
\hline & $\begin{array}{l}\text { for non-smoking } \\
\text { related personal } \\
\text { injury or death } \\
\text { arising from } \\
\text { contravention of } \\
\text { provisions relating } \\
\text { to unfair practices } \\
\text { such as misleading } \\
\text { or deceptive } \\
\text { conduct or false or } \\
\text { misleading } \\
\text { representations }\end{array}$ & $\begin{array}{l}\text { impairment } \\
\text { ('WPI') of more } \\
\text { than five per cent; } \\
\text { loss of a foetus; } \\
\text { loss of a breast; } \\
\text { hearing loss of } \\
\text { more than five per } \\
\text { cent; } \\
\text { permanent } \\
\text { psychiatric } \\
\text { impairment of } \\
\text { more than } 10 \text { per } \\
\text { cent (but not } \\
\text { psychiatric and } \\
\text { psychological } \\
\text { injury arising from } \\
\text { a physical injury), } \\
\text { unless the fault is } \\
\text { sexual assault or } \\
\text { misconduct, or an } \\
\text { intentional act to } \\
\text { cause injury. }\end{array}$ & \\
\hline $\begin{array}{l}\text { Injury } \\
\text { assessment } \\
\text { approach }\end{array}$ & $\begin{array}{l}\text { Judicial assessment } \\
\text { in which the judge } \\
\text { hearing the case } \\
\text { makes the } \\
\text { assessment. }\end{array}$ & $\begin{array}{l}\text { Medical } \\
\text { assessment based } \\
\text { on: } \\
\text { Physical injuries - } \\
\text { 4th edition of the } \\
\text { American Medical } \\
\text { Association Guides } \\
\text { to the Evaluation of } \\
\text { Permanent } \\
\text { Impairment. } \\
\text { Psychiatric injuries } \\
\text { - The Clinical } \\
\text { Guidelines to the } \\
\text { Rating of } \\
\text { Psychiatric } \\
\text { Impairment } \\
\text { prepared by the } \\
\text { Medical Panel } \\
\text { (Psychiatry) } \\
\text { Melbourne, in } \\
\text { October 1997. }\end{array}$ & $\begin{array}{l}\text { Judicial assessment } \\
\text { in which the judge } \\
\text { hearing the case } \\
\text { makes the } \\
\text { assessment. }\end{array}$ \\
\hline $\begin{array}{l}\text { Damages } \\
\text { assessment } \\
\text { approach }\end{array}$ & $\begin{array}{l}\text { Common law } \\
\text { principles }\end{array}$ & $\begin{array}{l}\text { Common law } \\
\text { principles }\end{array}$ & $\begin{array}{l}\text { Common law } \\
\text { principles }\end{array}$ \\
\hline
\end{tabular}




\begin{tabular}{|c|c|c|c|}
\hline $\begin{array}{l}\text { Calculation } \\
\text { of damages } \\
\text { to be } \\
\text { awarded }\end{array}$ & $\begin{array}{l}\text { A graduated scale } \\
\text { for injuries } \\
\text { between } 15 \text { per } \\
\text { cent and } 32 \text { per } \\
\text { cent of a most } \\
\text { extreme case. } \\
\text { From } 33 \text { per cent } \\
\text { till } 100 \text { per cent of } \\
\text { a most extreme } \\
\text { case, the amount of } \\
\text { damaged awarded } \\
\text { is the same } \\
\text { percentage of the } \\
\text { cap on damages. }\end{array}$ & $\begin{array}{l}\text { Courts may have } \\
\text { reference to } \\
\text { previous court } \\
\text { decisions. }\end{array}$ & $\begin{array}{l}\text { From } 15 \text { per cent to } \\
33 \text { per cent, a fixed } \\
\text { percentage of the } \\
\text { maximum. } \\
\text { Courts may have } \\
\text { reference to } \\
\text { previous court } \\
\text { decisions. }\end{array}$ \\
\hline $\begin{array}{l}\text { Cap on } \\
\text { damages }\end{array}$ & $\begin{array}{l}\text { A } \$ 250,000 \text { indexed } \\
\text { annually to CPI. }\end{array}$ & $\begin{array}{l}\text { A } \$ 371,380 \text { indexed } \\
\text { annually to } \\
\text { Melbourne CPI. }\end{array}$ & $\begin{array}{l}\text { A } \$ 350,000 \text { indexed } \\
\text { to AWE for NSW. }\end{array}$ \\
\hline $\begin{array}{l}\text { Interest on } \\
\text { damages }\end{array}$ & No & Yes & No \\
\hline
\end{tabular}

\begin{tabular}{|c|c|c|c|}
\hline Elements & Qld & $\mathbf{S A}$ & WA \\
\hline $\begin{array}{l}\text { Name of the } \\
\text { Act(s) }\end{array}$ & $\begin{array}{l}\text { Civil Liability Act } \\
2003\end{array}$ & $\begin{array}{l}\text { Wrongs (Limitation } \\
\text { and Damages for } \\
\text { Personal Injury) } \\
\text { Amendment Act } \\
2002\end{array}$ & $\begin{array}{l}\text { Civil Liability Act } \\
2002\end{array}$ \\
\hline $\begin{array}{l}\text { Threshold } \\
\text { on damages }\end{array}$ & No & $\begin{array}{l}\text { Seven days of } \\
\text { significant } \\
\text { impairment to } \\
\text { victim's ability to } \\
\text { lead a normal life } \\
\text { or A } \$ 2750 \text { medical } \\
\text { expenses } \\
\text { reasonably incurred } \\
\text { due to the injury. }\end{array}$ & $\begin{array}{l}\text { A } \$ 12,000 \text { indexed } \\
\text { to the Wage Cost } \\
\text { Index for WA. }\end{array}$ \\
\hline $\begin{array}{l}\text { Injury } \\
\text { assessment } \\
\text { approach }\end{array}$ & $\begin{array}{l}\text { Generally WPI } \\
\text { with latitude in } \\
\text { assessment } \\
\text { methods provided } \\
\text { methodological } \\
\text { details are } \\
\text { provided, but } \\
\text { courts are to prefer } \\
\text { assessments }\end{array}$ & $\begin{array}{l}\text { Judicial assessment } \\
\text { in which the judge } \\
\text { hearing the case } \\
\text { makes the } \\
\text { assessment. }\end{array}$ & $\begin{array}{l}\text { Judicial assessment } \\
\text { in which the judge } \\
\text { hearing the case } \\
\text { makes the } \\
\text { assessment. }\end{array}$ \\
\hline
\end{tabular}




\begin{tabular}{|c|c|c|c|}
\hline & $\begin{array}{l}\text { according to the } \\
\text { fifth edition of the } \\
\text { AMA guidelines } \\
\text { all injuries other } \\
\text { than scarring and } \\
\text { mental disorders. }\end{array}$ & & \\
\hline $\begin{array}{l}\text { Damages } \\
\text { assessment } \\
\text { approach }\end{array}$ & $\begin{array}{l}\text { Statute-based on a } \\
100 \text {-point scale of } \\
\text { Injury Scale Value } \\
\text { ("ISV") on the } \\
\text { degree of injury } \\
\text { with reference to a } \\
\text { guide on particular } \\
\text { ranges of ISV for } \\
162 \text { types of } \\
\text { injuries along with } \\
\text { rules on applying } \\
\text { those ranges, and } \\
\text { ISV attributed to } \\
\text { similar injuries in } \\
\text { prior proceedings. }\end{array}$ & $\begin{array}{l}\text { Statute-based } \\
\text { according to a } \\
\text { numerical scale } \\
\text { between zero and } \\
60 \text { reflecting } 60 \\
\text { equal gradations of } \\
\text { non economic loss } \\
\text { from not severe } \\
\text { enough to justify } \\
\text { damages to the } \\
\text { gravest possible } \\
\text { kind. }\end{array}$ & $\begin{array}{l}\text { Common law } \\
\text { principles }\end{array}$ \\
\hline $\begin{array}{l}\text { Calculation } \\
\text { of damages } \\
\text { to be } \\
\text { awarded }\end{array}$ & $\begin{array}{l}\text { Formula with ISV } \\
\text { at the lower end of } \\
\text { the injury scale } \\
\text { worth } \\
\text { exponentially less } \\
\text { than those at the } \\
\text { higher end. } \\
\text { No damages for } \\
\text { loss of consortium/ } \\
\text { servitium (loss of } \\
\text { comfort/services) } \\
\text { where general } \\
\text { damages are less } \\
\text { than A } \$ 30,000 .\end{array}$ & $\begin{array}{l}\text { Numerical value } \\
\text { corresponds to a } \\
\text { dollar figure fixed } \\
\text { by reference to an } \\
\text { indexed sliding } \\
\text { scale skewed so } \\
\text { that damages for } \\
\text { minor injuries are } \\
\text { much less than } \\
\text { damages for } \\
\text { serious injuries, but } \\
\text { subject to } \\
\text { deductible of the } \\
\text { same amount as } \\
\text { threshold. }\end{array}$ & $\begin{array}{l}\text { Damages amount } \\
\text { between } A \$ 12,000 \\
\text { and } A \$ 36,500 \text { is } \\
\text { subject to } \\
\text { A } \$ 12,000 \\
\text { deductible whereas } \\
\text { that greater than } \\
\$ 36,500 \text { but less } \\
\text { than } \$ 48,500 \text { is } \\
\$ 12,000 \text { less } \\
(\text { damages assessed } \\
\text { minus } \\
\$ 36,500) \text {. } \\
\text { Courts may have } \\
\text { reference to } \\
\text { previous court } \\
\text { decisions. }\end{array}$ \\
\hline $\begin{array}{l}\text { Cap on } \\
\text { damages }\end{array}$ & $\mathrm{A} \$ 250,000$ & $\begin{array}{l}\text { A } \$ 241,500 \text { indexed } \\
\text { annually to } \\
\text { Adelaide CPI. }\end{array}$ & Nil \\
\hline $\begin{array}{l}\text { Interest on } \\
\text { damages }\end{array}$ & No & No & Yes \\
\hline
\end{tabular}




\begin{tabular}{|c|c|c|c|}
\hline Elements & Tas & ACT & NT \\
\hline $\begin{array}{l}\text { Name of the } \\
\operatorname{Act}(\mathrm{s})\end{array}$ & $\begin{array}{l}\text { Civil Liability Act } \\
2002\end{array}$ & $\begin{array}{l}\text { The Civil Law } \\
\text { (Wrongs) } \\
\text { Amendment Act } \\
2003 \text { (No 2) }\end{array}$ & $\begin{array}{l}\text { Personal Injuries } \\
\text { (Liabilities and } \\
\text { Damages) Act } \\
2003\end{array}$ \\
\hline $\begin{array}{l}\text { Threshold on } \\
\text { damages }\end{array}$ & $\begin{array}{l}\text { A } \$ 4000 \text { indexed } \\
\text { annually to Hobart } \\
\text { CPI. }\end{array}$ & No & $\begin{array}{l}\text { Permanent } \\
\text { impairment of five } \\
\text { per cent of the } \\
\text { whole person. }\end{array}$ \\
\hline $\begin{array}{l}\text { Injury } \\
\text { assessment } \\
\text { approach }\end{array}$ & $\begin{array}{l}\text { Judicial } \\
\text { assessment in } \\
\text { which the judge } \\
\text { hearing the case } \\
\text { makes the } \\
\text { assessment. }\end{array}$ & $\begin{array}{l}\text { Judicial assessment } \\
\text { in which the judge } \\
\text { hearing the case } \\
\text { makes the } \\
\text { assessment. }\end{array}$ & $\begin{array}{l}\text { Medical } \\
\text { assessment based } \\
\text { on the AMA guide } \\
\text { to permanent } \\
\text { impairment }\end{array}$ \\
\hline $\begin{array}{l}\text { Damages } \\
\text { assessment } \\
\text { approach }\end{array}$ & $\begin{array}{l}\text { Common law } \\
\text { principles }\end{array}$ & $\begin{array}{l}\text { Common law } \\
\text { principles }\end{array}$ & $\begin{array}{l}\text { Statute-based } \\
\text { according to the } \\
\text { degree of } \\
\text { permanent } \\
\text { impairment. }\end{array}$ \\
\hline $\begin{array}{l}\text { Calculation } \\
\text { of damages } \\
\text { to be } \\
\text { awarded }\end{array}$ & $\begin{array}{l}\text { Subject to } \\
\text { deductible which } \\
\text { is the same amount } \\
\text { as threshold but } \\
\text { reduces according } \\
\text { to a sliding scale to } \\
\text { zero when awards } \\
\text { of damages reach } \\
\text { A } \$ 20000 \text { which is } \\
\text { indexed to Hobart } \\
\text { CPI. Courts may } \\
\text { have reference to } \\
\text { previous court } \\
\text { decisions. }\end{array}$ & $\begin{array}{l}\text { Courts may have } \\
\text { reference to } \\
\text { previous court } \\
\text { decisions. }\end{array}$ & $\begin{array}{l}\text { A sliding scale for } \\
\text { five per cent to } 15 \\
\text { per cent permanent } \\
\text { impairment of the } \\
\text { whole person. } \\
\text { From } 33 \text { per cent } \\
\text { till } 100 \text { per cent, } \\
\text { the amount of } \\
\text { damaged awarded } \\
\text { is the same } \\
\text { percentage of the } \\
\text { cap on damages. }\end{array}$ \\
\hline $\begin{array}{l}\text { Cap on } \\
\text { damages }\end{array}$ & Nil & Nil & $\begin{array}{l}\text { A } \$ 350000 \text { indexed } \\
\text { to AWE for NT. }\end{array}$ \\
\hline $\begin{array}{l}\text { Interest on } \\
\text { damages }\end{array}$ & Yes & Yes & No \\
\hline
\end{tabular}



